\title{
New polymorphic microsatellite markers in the greater false vampire bat Megaderma lyra (Chiroptera: Megadermatidae)
}

\author{
Anna Tereba • Dagmar Č́ž́ková • Arasamuthu Arul Sundari • \\ Koilmani Emmanuvel Rajan • Wiesław Bogdanowicz
}

Received: 19 April 2011 / Accepted: 25 April 2011/Published online: 13 May 2011

(C) The Author(s) 2011. This article is published with open access at Springerlink.com

\begin{abstract}
In this study, we present 10 new microsatellite markers for a carnivorous bat, Megaderma lyra (family Megadermatidae). Out of 10 loci, only one locus showed a statistically significant value $(P<0.05)$ for $\mathrm{F}_{\text {Is }}$ coefficient, and one was found to be $\mathrm{X}$-linked. These loci were tested on 189 individuals representing four populations from southern India, and all loci were highly polymorphic. The mean number of observed alleles per locus was 10.1 (range from 6 to 16). Expected heterozygosity values ranged from 0.54 to 0.91 . These polymorphic markers will be used to examine population structure, mating and dispersal behaviour of M. lyra in the field.
\end{abstract}

Keywords Chiroptera - Megaderma lyra .

Microsatellites · Polymorphism

Megaderma lyra is a gleaning, carnivorous bat feeding on large arthropods and small vertebrates such as frogs, geckoes, lizards, fish, mice, birds, and even smaller bat species. It has a wide distributional range, from Afghanistan, Pakistan, India, Sri Lanka to Myanmar, South China, Malaysia and the Philippines (Bates and Harrison 1997). It

A. Tereba $(\bowtie) \cdot$ W. Bogdanowicz

Museum and Institute of Zoology, Polish Academy of Sciences,

Wilcza 64, 00-679 Warszawa, Poland

e-mail: atereba@miiz.waw.pl

D. Č́̌žková

Department of Population Biology, Institute of Vertebrate Biology, Academy of Sciences of the Czech Republic, Brno, Czech Republic

A. A. Sundari - K. E. Rajan

Department of Animal Science, School of Life Sciences,

Bharathidasan University, Thiruchirappalli 620 024, India forms small colonies, including both males and females, and roosts in caves, attics of houses, and artificial underground tunnels (Brosset 1962). Evidently, this is a fascinating species of bat, however little is known about its genetic structure and diversity. Integrating genetic data into the research on this species is essential for understanding complex processes in its biology and ecology and to design conservation strategies. Recently, Rajan et al. (2009) published a paper describing 8 highly polymorphic nuclear microsatellite loci, but this number of markers may not be sufficient to infer detailed genetic comparisons. Koskinen et al. (2004) postulated that at least 10 polymorphic loci are needed for non-erroneous inference in a genetic population. In the present paper we describe 10 additional microsatellite loci and now the combination of both data sets will provide an ideal tool for the study of genetic relationships in M. lyra.

To obtain sequences of microsatellite loci and their flanking regions we constructed two genomic libraries enriched for common vertebrate microsatellite motives (TG and ATCT), using the strategy of Estoup and Martin (1996). Total DNA was extracted from the wing membrane biopsy punch (see Whortington Wilmer and Barratt 1996) of a single male of $M$. lyra using DNeasy Tissue Kit (Qiagen) and digested with RSAI restriction enzyme (Promega). Fragments of 500-900 bp length were extracted from the agarose gel, ligated to RSA21 and RSA25 adaptors (Edwards et al. 1996), and amplified using RSA21 oligos as PCR primers. Biotinylated oligo probes (TG) 10 and (ATCT) were hybridized to the diluted PCR product and the DNA molecules containing respective motives were selected using streptavidin magnetic particles (Promega). Enriched DNA was PCR amplified, ligated to a plasmid vector (Promega) and transformed into JM109 competent cells (Promega). Ca. 500 clones for each library were transferred 
Table 1 Primer sequences and characterization of 10 microsatellite loci developed for $M$. lyra (GenBank accession numbers JF907000JF907009)

\begin{tabular}{|c|c|c|c|c|c|c|c|c|}
\hline Locus & Repeat motif & Primer sequence $\left(5^{\prime}-3^{\prime}\right)$ & $\mathrm{T}_{\mathrm{m}}\left({ }^{\circ} \mathrm{C}\right)$ & No. alleles & Size range (bp) & $\mathrm{H}_{\mathrm{O}}$ & $\mathrm{H}_{\mathrm{E}}$ & $\mathrm{F}_{\mathrm{IS}}$ \\
\hline MlA10 & (TG)15 & $\begin{array}{l}\text { F: AAGTCCCTTGGGTGACTC } \\
\text { R: GAAGTCAGCTGCTTTTCAGT }\end{array}$ & 57 & 11 & $153-175$ & 0.820 & 0.823 & 0.005 \\
\hline MID1 & (TG) $13 \mathrm{C}(\mathrm{TG}) 11$ & $\begin{array}{l}\text { F: TAAGAACACTGGGAAACCAC } \\
\text { R: GGAGACTTGTTTCTGTGGAG }\end{array}$ & 57 & 10 & $207-237$ & 0.724 & 0.765 & 0.053 \\
\hline MlD11 & (TG)21 & $\begin{array}{l}\text { F: ACAAAATGTGAATCAAAGCA } \\
\text { R: CGCTCAGTCATTTTCAGTTT }\end{array}$ & 57 & 11 & $177-227$ & 0.675 & 0.726 & 0.070 \\
\hline MlD12 & (TG)15 & $\begin{array}{l}\text { F: CTTTAGGGACCTCCTCTCTG } \\
\text { R: TGCCATTCTGAAGTAGAACA }\end{array}$ & 57 & 10 & $215-237$ & 0.702 & 0.691 & -0.016 \\
\hline MIE6 & (TG) 15 & $\begin{array}{l}\text { F: AAAATGAGGGCATTTATGG } \\
\text { R: TTTAAGGCTCTTCATTGCTC }\end{array}$ & 55 & 11 & $158-178$ & 0.820 & 0.875 & $0.063^{\mathrm{b}}$ \\
\hline MlF6 & (TG) $8 \mathrm{CA}(\mathrm{TG}) 8$ & $\begin{array}{l}\text { F: TTACGTGAAGATGGCTACAA } \\
\text { R: GCACATACCACACACGTAAG }\end{array}$ & 55 & 8 & $163-177$ & 0.526 & 0.563 & 0.066 \\
\hline MlG3 & (TG)17 & $\begin{array}{l}\text { F: CTACTCCACTGTTGCTGACA } \\
\text { R: CACTCTGTGCTACTAAGTCTGC }\end{array}$ & 55 & 11 & $144-164$ & 0.824 & 0.845 & 0.025 \\
\hline MlG11 & $(\mathrm{ATCT}) 12$ & $\begin{array}{l}\text { F: TTTAGATACAATTGACACATAGCA } \\
\text { R: TGGAAAATGATGATCACAAG }\end{array}$ & 55 & 7 & $172-192$ & 0.634 & 0.677 & 0.063 \\
\hline M1A3 & (TG)9T(GA)15 & $\begin{array}{l}\text { F: ACACGAGCATGTGCCTAT } \\
\text { R: AGCTCCCTCCAAGTCTTTAC }\end{array}$ & 55 & 6 & $150-162$ & 0.486 & 0.537 & 0.095 \\
\hline $\mathrm{MlA}^{\mathrm{a}}$ & (TC)20(TG)5C(TG)4 & $\begin{array}{l}\text { F: ATAGGGGGTATCAGGACAAT } \\
\text { R: GCATGCATATTGGAGTAGGT }\end{array}$ & 55 & 16 & $184-220$ & 0.837 & 0.912 & 0.083 \\
\hline Mean & & & & 10.1 & & 0.675 & 0.741 & 0.090 \\
\hline
\end{tabular}

$T_{m}$ annealing temperature, No. alleles number of alleles, $H_{O}$ observed heterozygosity, $H_{E}$ expected heterozygosity, $F_{I S}$ fixation index

${ }^{\text {a }}$ Locus MlA4 is located on the $\mathrm{X}$ chromosome. $\mathrm{H}_{\mathrm{O}}$ and $\mathrm{H}_{\mathrm{E}}$ are calculated for females only

b Significant value of $\mathrm{F}_{\mathrm{IS}}(P<0.05)$

onto Hybond-N + membranes (Amersham) and screened using digoxigeninend-labelled (TG) 10 and $(\mathrm{ATCT})_{5}$ probes. The 96 positive clones were sequenced in Macrogen (South Korea). Sequences were checked with BIOEDIT ver. 7.0.5. (Hall 1999) for regular microsatellite motives with flanking regions of sufficient length. Primers were designed using PRIMER 3 v. 0.4.0 (Rozen and Skaletsky 2000) and tested for 15 loci, of which 10 polymorphic loci were chosen for further analyses.

We amplified these loci in 189 individuals of M. lyra from four colonies from southern India. Conditions for the PCR reaction were as follows: $96^{\circ} \mathrm{C}$ for $3 \mathrm{~min}, 35$ cycles at $96^{\circ} \mathrm{C}$ for $30 \mathrm{~s}, 55^{\circ} \mathrm{C} / 57^{\circ} \mathrm{C}$ for $45 \mathrm{~s}, 72^{\circ} \mathrm{C}$ for $55 \mathrm{~s}$, and final cycle $94^{\circ} \mathrm{C}$ for $30 \mathrm{~s}, 55^{\circ} \mathrm{C} / 57^{\circ} \mathrm{C}$ for $1 \mathrm{~min} .72^{\circ} \mathrm{C}$ for $5 \mathrm{~min}$. Amplifications were carried out in $15 \mu \mathrm{l}$ with $0,5 \mu \mathrm{l}$ of DNA (10-50 ng), 7.5 RedTag Ready Mix (Sigma-Aldrich), 5 pmol of each primer and $5 \mu \mathrm{l}$ of PCR water. Each forward primer was fluorescent labelled with WellRED dyes (Beckman Coulter, Inc.). Loci MlA10, MID11, MID12 and MIG3 were labelled with D2, loci MID1, MIE6 and MIF6 were labelled with D3, loci MlG11, MlA3 and MlA4 were labelled with D4. We run samples in two post-PCR multiplex sets, first with loci MlA10, MlD12, MlF6, MlA3, and
MlA4, and second with loci MID1, MlD11, MlE6, MlG3, and MlG11. Allele lengths were scored on a CEQ 8000 sequencer (Beckmann-Coulter), with internal lane standard (DNA Size Standard Kit-400, Beckmann-Coulter). Levels of heterozygosity were calculated in Arlequin ver 3.11 (Excoffier et al. 2005) and $F_{I S}$ coefficients were obtained using F $_{\text {STAT }}$ ver. 2.9.3.2 (Goudet 1995, 2001).

All analysed loci were highly polymorphic with the number of alleles ranging from 6 to 16. The mean observed heterozygosity was equal to 0.675 (Table 1). One of these loci (MlE6) showed a statistically significant value $(P<$ 0.05 ) for $F_{I S}$ based on the randomization test implemented in $\mathrm{F}_{\text {STAT }}$ (1000 randomizations performed), probably resulting from the presence of null alleles. In one locus (MlA4) we observed that all males (41 individuals) were homozygotes. This indicates that we scored a marker located on the $\mathrm{X}$ chromosome. These 10 new markers, together with those previously developed (Rajan et al. 2009), give a unique opportunity for performing detailed genetic studies of M. lyra, and will add new information to other areas of research such as classical capture-recapture (Sripathi et al. 2004) or population structure studies (Raghuram et al. 2006). 
Open Access This article is distributed under the terms of the Creative Commons Attribution Noncommercial License which permits any noncommercial use, distribution, and reproduction in any medium, provided the original author(s) and source are credited.

\section{References}

Bates PJ, Harrison DL (1997) Bats of the Indian subcontinent. Harrison Zoological Museum Publication, England

Brosset A (1962) Bats of central and western India. J Bombay Nat Hist Soc 59:608-613

Edwards KJ, Barker JHA, Daly A, Jones C, Karp A (1996) Microsatellite libraries enriched for several microsatellite sequences in plants. Biotechniques 20:758-760

Estoup A, Martin O (1996) Marqueurs microsatellites: isolement ả l'aide de sondes non-radioactives, caractérisation et mise au point. Institut National Agronomique-Paris Grignon (INA-PG). http://www.inapg.inra.fr/dsa/microsat/microsat.html

Excoffier L, Laval G, Schneider S (2005) ARLEQUIN ver. 3.0: an integrated software package for population genetics data analysis. Evol Bioinform Online 1:47-50

Goudet J (1995) Fstat (version 1.2): a computer program to calculate $F$-statistics. J Hered 86:485-486

Goudet J (2001) Fstat, a program to estimate and test gene diversities and fixation indices (version 2.9.3). Accessed on http://www. unil.ch/izea/softwares/fstat.html. Updated from Goudet (1995)
Hall TA (1999) BioEdit: a user-friendly biological sequence alignment editor and analysis program for Windows 95/98/NT. Nucl Acids Symp Ser 41:95-98

Koskinen MT, Hirvonen H, Landry P-A, Primmer CR (2004) The benefits of increasing the number of microsatellites utilized in genetic population studies: an empirical perspective. Hereditas 141:61-67

Raghuram H, Chattopadhyay B, Nathan PT, Sripathi K (2006) Sex ratio, population structure and roost fidelity in a free-ranging colony of Indian false vampire bat Megaderma lyra. Current Sci 91:965-968

Rajan KE, Sundari AA, Marimuthu G (2009) Isolation and characterization of microsatellite loci in the Indian false vampire bat Megaderma lyra. Conserv Genet Resour 1:369-371

Rozen S, Skaletsky H (2000) Primer 3 on the WWW for general users and for biologist programmers. In: Krawetz S, Misener S (eds) Bioinformatics methods and protocols: methods in molecular biology. Humama Press. Totowa, NJ, pp 365-386

Sripathi K, Raghuram H, Rajasekar R, Karuppudurai T, Abraham SG (2004) Population size and survival in the Indian false vampire bat Megaderma lyra. Acta Chiropterol 6:145-154

Whortington Wilmer WJ, Barratt EM (1996) A non-lethal method of tissue sampling for genetic studies of chiropterans. Bat Res News 37:1-3 